\title{
Chromosome Number of Cubiu, Solanum sessiliflorum Dunal, a Solanaceous Truil of the Brazilian Amazonas
}

\author{
Caridarl il. I'urcell'
}

\section{I.VTRODE!CITON}

Several South Ameriean species of Solanareas produce edible fruits mainly used by local Indian tribes $(1,2) .^{2}$ ()ne of the lesi known of these fruits is cubru. The plaut grows expecially in the westerumost part of the Fitado da Amazonas, along the solinôses livere, where it is found both wild and cultivuled. Fvans et al, reported that "the fruils ate said to be edible" (2).

The vernacular Sengatu name cubiyn is applied in the Columbian Vaujes to several sperisu of Solanum (2). It secms to be a rather generic name used for a number of species of solanum with edible fruits. In the Mantux region of the Brapilian Amazonas the mame cubiu ayplies to Solanum. sessiliflorum Dumal.

Being in posisesion of a small sample of Solanum sessiliflorum Dumal reeds, and feeling that this species might be useful for a breding program of umanjilla, solanum quiloenses lamarek, we sowed them in order to study the basic rhamateristics and rhromosome number of the plant.

\section{MA'TERIALS AND METIIODS}

A ribín fruit bought from a Manaus street vendor by J). Niilo Tirki in Jume 196t, provided the initial seeds for this study. The fruit was identified by Dr. Willian Rodrigues, Botanist at the lnstituto Sicronal de Pesquisas do Ama\%onas, Mamaus, Brazil.

The original seeds were planted on the farm of Dr. Niilo Virkiki in (Cupey, P.R., in August 196t. Flowers were fixed in Newromer's fluid or with aretic alcohol. Both methods provided identimal results. The anthers were macerated in hot $N \mathrm{HCl}$ with several drops of iton-acetoramine. Anthers were crushed with the use of foresps, and then scuasshed in the shain with a simple wooden presi designed by Dr. Veiklio Solsa. ${ }^{3}$

Seeds from the first mature fruil produced at Dr. Virkki's farm were

1 Research Assistnnt in Plaut Breeding, Agricultural lixperiment Station, I'niversity of Puerto Riro, Rio Piedras, P.K. The author wishow to express her sincere gratitude to Dr. Niilo lirkki, under whose direction this study wits conducted and who supplied the material used.

${ }^{2}$ Italic numbers in parentheses reler fo literature Cited, p. 251.

3 Departnent of (ieneties, Liniversity of Helsinki, Holsinki. Finland. 


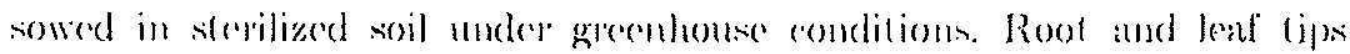

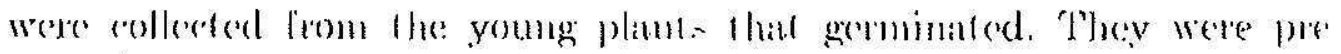

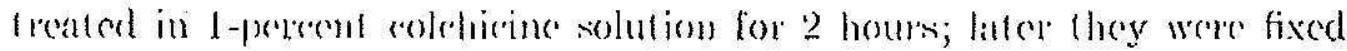

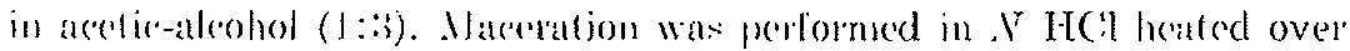

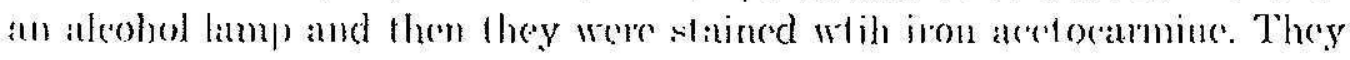
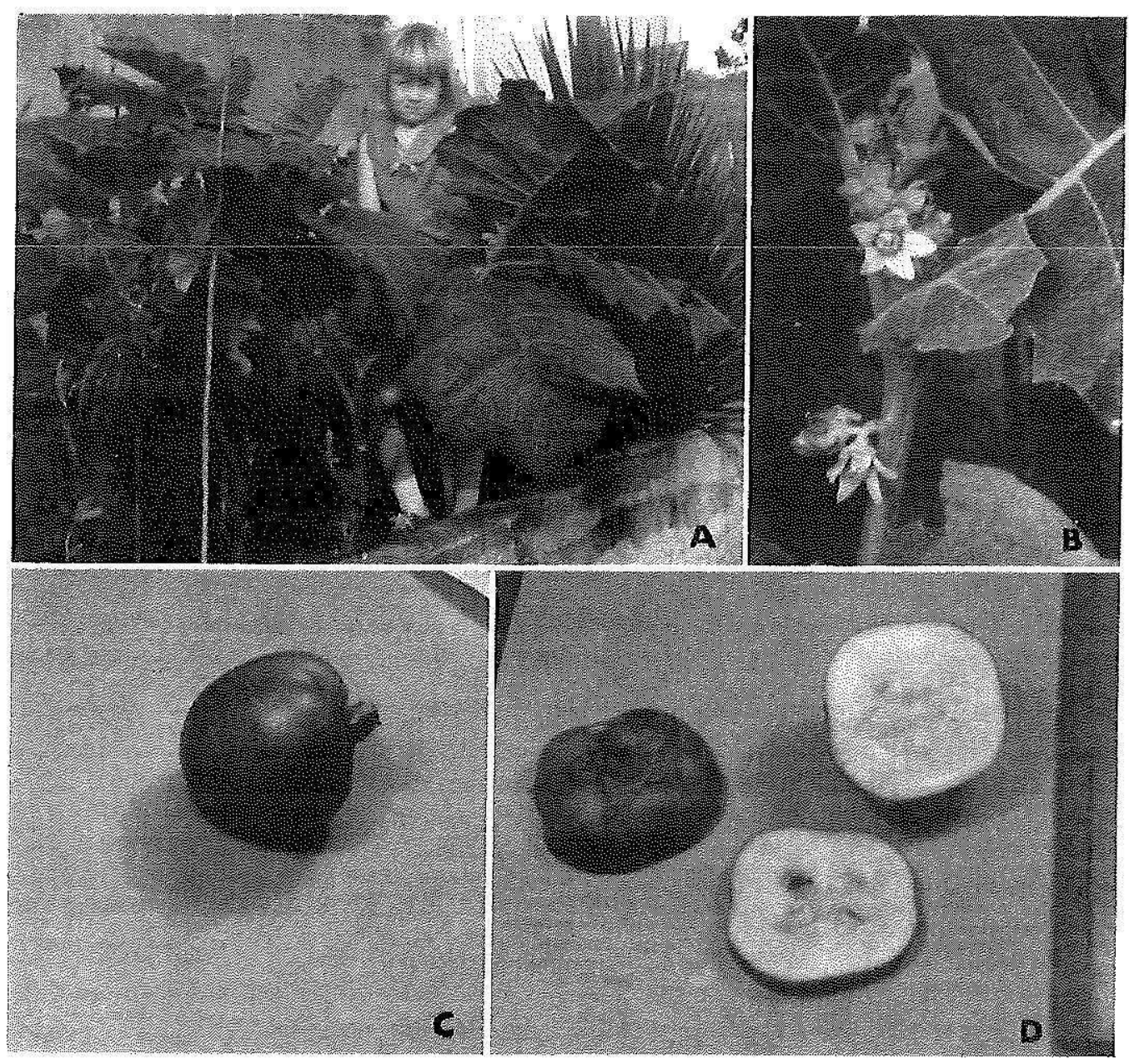

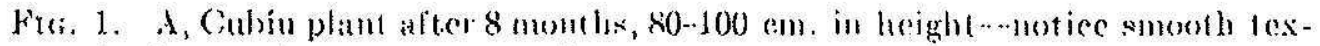

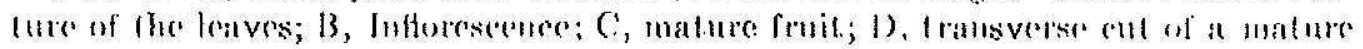
fruit.

wore rewsted with forecps and squatshed in the stain the same way that were the anthers.

The photomicrographis were taken with a Leity Makam camera mouned on a Leit: Ortholux rescom microseope; final magnifications $820 \times$.

\section{OBSLIRVATENS}

liven though (be serds were planted during the month of August, we are sure that it would have been a better prarelies lo do this during the 


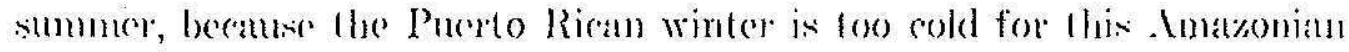

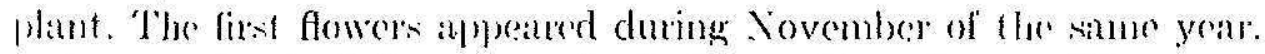

Apparently the infloreseenes is similar to that of amamjilla, as well as ollere morphologisal rhatacters. They differ in the lotal absenee of spines in the rubitu, while several st. quilocenses rarioties have them (lig. 1,13).

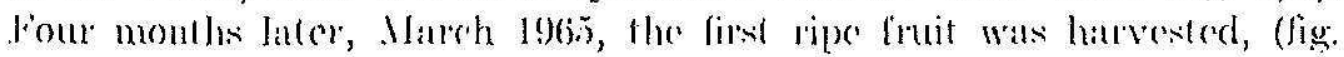
$1,(-1))$. The fruit is ovoid, purple-red when ripe and rovered wilh asily deciduous white hairs. The pulp is yellowish. The ripening fout (ums from vellow to purplered when it is rijer. Secds are very mumerous, flat, oval in

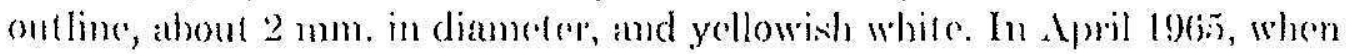
the plant: were 8 month old, they had reached a hright of 8010100 ('m.

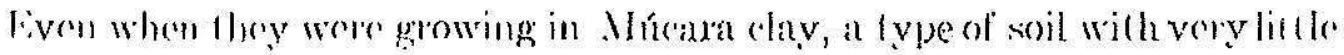
lumms, and with irregular additions of fertilime (only lertagreen was added) Hory grow to be very beallhy and strong (lig. 1, i).

It was observed that the phuts were altacked by fwo diflerend inseds. 'The l'sara periosolis Walker, raused a grent cteal of dimage during the monthe of August and . November. I mealy bug, P'seudococeus spe, altateded rontimususly the voung parts of the plants without amsing seriots damage 10 it.

Most of the anthers studied presented tapefum divisions while nome presented P.IC divisions.

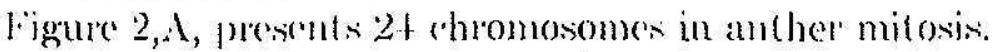

Besides root-fips, several rolyledoms were chosen 10 bes shadied in rases when the sods took a longer time to germinate. They proved to be befles: matcrial than the root-tijs beranse they are softer. In this material the

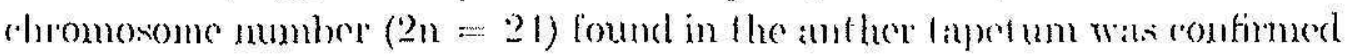
( (ig. 2, 3 ).

\section{DIsfission}

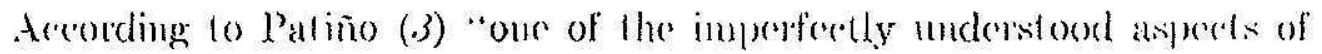

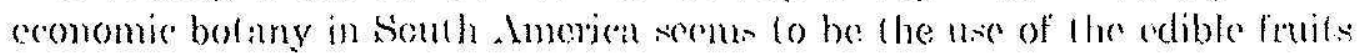
of sumdey spereics of solamum!"

The rubiu is systematically elose to He matujilla which wis introduerel

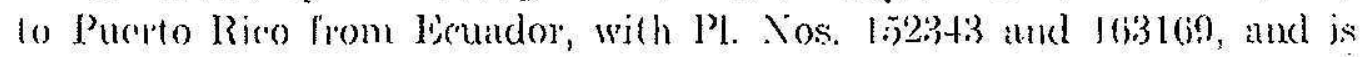
indigenous to the equinotial region (3). The uannjilla suffers from haterial wilt in Pucto Rico.

It is expected that species from humid tropical lowlands have developed more resistance towads all kinds of pest shan plants from a more sipe rialized rlimale. Therefore plant introductions from humid Tropies may prove to be more suitable for Puerto Rieo than introductions from ollue fropieal rites. Fven speries with low utility as surh could serve as somers of genes for resistance. A clofailed study of the prosible: resistances of (ubiut is in progrest. 


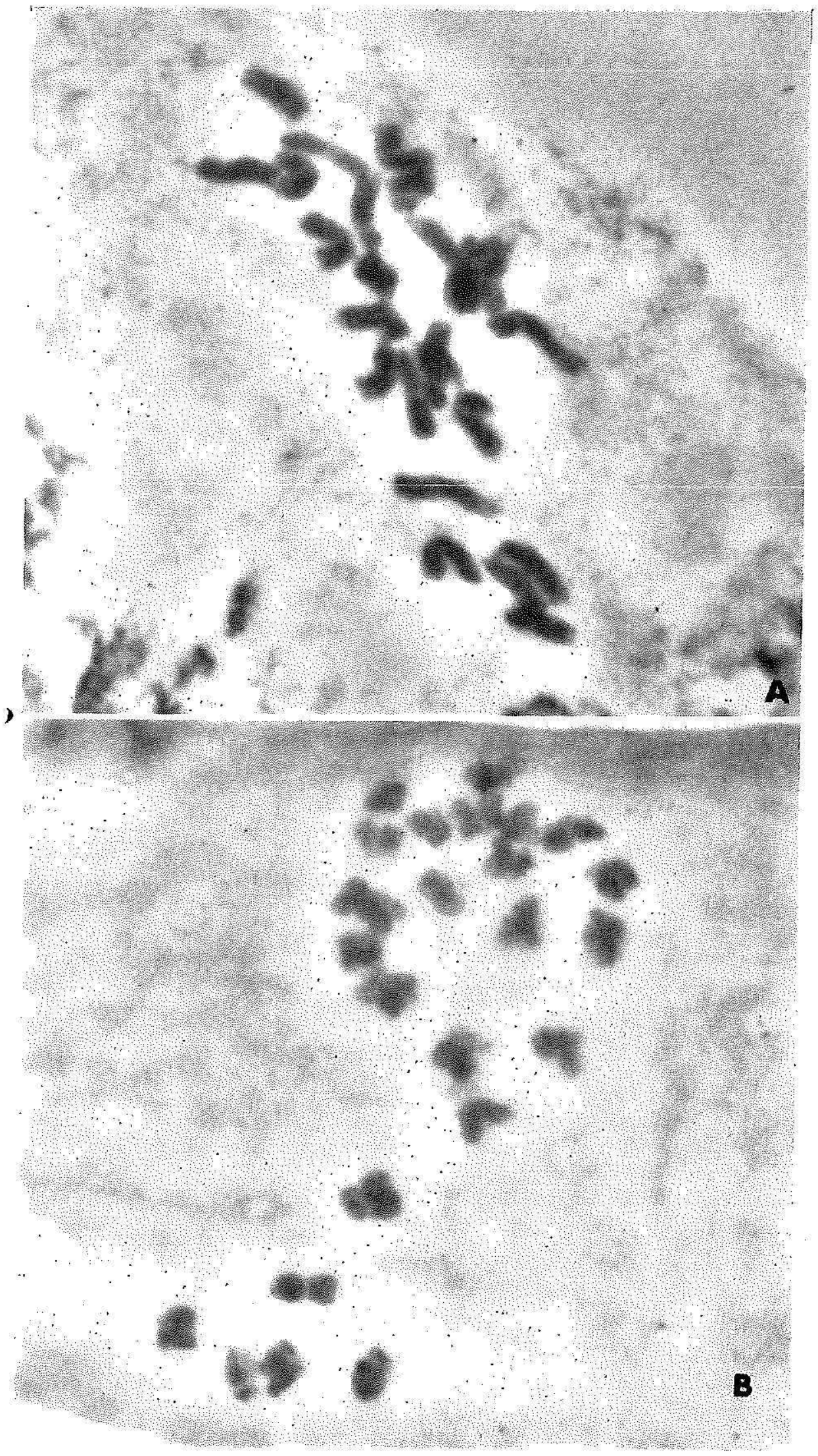

lis:. 2. A. Mulaphase of :nl her nilusis of cubiu plant; $B$, metaphase encountered in the colytedon tissuc, $2 n=21$. 
The group of wild or half-eullivated Solanareams of South Amoriea desorese the attention of the brecters, because: 1, New wectul fruits could

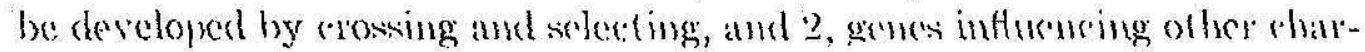

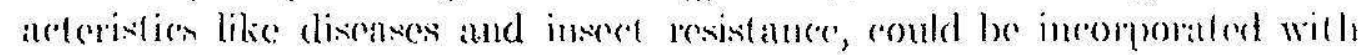
revisting cultivated Solantaresus.

\section{SLINIIKY}

Cubiu, Solanum sessitiflorum Dunal, is an Amazonian relative of the narunjillat (Solanum quilonenses Lamaurk), an e(puatorian lruit plant intro)duserd carlice in Puerto Rico. The rhromosone number has been determined and proved to be $2 \mathrm{n}$-... 221. It is being studed for resistance to bartorial wilt and will be werked for other pests that atlack Solanareans in Pucroto Riro.

\section{RESLMII.)}

El rubíu, Solanum sessiliflorum Dunal, es ma cspoecie de las solanáceande la Región del Amazonas, que tiene atinidad botánic'a con lat naminjilla (Solanum quitoenses Lamarck), plantat trutal de la Región Firuatorial que se introdujo a Puerto Rico previamente. Sc detrrminó que el núnero de rromosomar del rubíu es $2 n=2 t$. Se están haciendo cstudios son exta planta para determina su resistencia 0 susceptibilidad a la marehitez bacteriana (bacterial wilt) y otris enfermedades gue alfectate a las volanáceati en Pucrto Rico.

\section{I.ITERATURE (ITED)}

1. Ducke, A., Pluntas de Cultura Pre-Colombima da Anamonia Brayilora. Notas sobre as especies ou formas espoutaneas que supostamento thes teriam dado origeu, Bol. Teeh. Inst. A grom. Vorle Nos. 8, 9 (194i).

2. Livans Nehulıes, Richurd, and Romero-Castaneda, Rafiel, Fdible fruits of Solanun in Columbia, Bot. Museum Lnafiets, Harvard l'niv. 19(10) : 235, 19 (22.

3. Paliño, Vietor Manuel, kdihle fruits of Solanum in Sonth Anerican Historic and (ieographic lieferences. Bor. Nuseum Leaflets, Harvard (niv. $19(10): 215,10)(2$. 